\title{
Risk As An Antecedent Variables Of Bank Soundness With Good Corporate Governance As A Moderating Variable On Private Commercial Banks Listed In The Indonesia Stock Exchange
}

\author{
Herizon \\ Department of Management, \\ Sekolah Tinggi Ilmu Ekonomi Perbanas Surabaya, Indonesia
}

\begin{abstract}
The sound banking industry is needed every country including Indonesia. Private commercial banks listed on the Indonesia Stock Exchange still have soundness problems, because in the last five years of 2012 until 2016 their soundness tends to decline as evidenced by the declining trend of soundness scores. The critical objective of this research is to investigate and know the antecedent variables of bank soundness and the ability of the GCG variable in influencing from risk to bank soundness. The population of this research is private commercial banks listed in Indonesia Stock Exchange and by using purposive sampling technique selected 22 banks as sample research. The period of this study is from 2012 to 2016 . The variables in this research include credit risk, market risk liquidity risk, operational risk and GCG as the independent variable and bank soundness as the dependent variable. Risk indicator data are collecting by downloading the financial statements for the last five years from the sites Financial Services Authority (OJK). Data about GCG was taken from annual bank report and bank soundness data taken from Infobank magazine. In conducting the research hypothesis proof, used WarpPLS software. The results obtained from this research are credit risk and operational risk performance into an antecedent variable of bank soundness because it has a significant effect on the bank soundness, while a market risk, liquidity risk, and GCG do not become antecedent variable bank soundness due to the insignificant effect on the bank soundness. GCG moderates the impact of credit risk, market risk, liquidity risk and operational risk to bank soundness.
\end{abstract}

Keywords: Credit risk, market risk, liquidity risk, operational risk, GCG, and soundness of banks

\section{INTRODUCTION}

The Indonesian banking industry has faced changes in the external environment since the issuance and enactment of Basel I documented in 1988, followed by amendments market risk in 1996, Basel II in 2004 and Basel III in 2009, all of which govern the imperative of application risk management and GCG at the bank.

The government of Indonesia through the Indonesian Central Bank (BI) and the Financial Services Authority (OJK) has responded to the changing environment of the banking industry by enacting regulations requiring the implementation of risk management as stipulated in the Indonesian Central Bank Regulation (PBI) number 5/8/PBI/2003 enhanced by PBI number 11/25/PBI/2009 and updated by the Financial Services Authority Regulation (POJK) number 18/ POJK.03/2016.

Then, both $\mathrm{BI}$ and OJK also strengthen the risk management implementation regulation by issuing and enacting regulations requiring the management of banks operating in Indonesia to implement good governance or GCG with the issuance and enactment of PBI number 8/4/PBI/2006 which has been subsequently refined by PBI number 8/14/PBI/2006. The 
Indonesian Central Bank Regulations are complemented by Circular Letter of the Indonesian Central Bank (SEBI) No. 9/12/DPNP/2007 enhanced by SEBI number 15/15/DPNP/2013. These regulations have been enhanced by the Financial Service Authority Regulation (POJK) number 55/POJK.03/2016 and the Financial Services Authority Circular Letter (SEOJK) number 13/SEOJK.03/2017 on the implementation of GCG for Commercial Banks.

Bank supervisors evaluate the implementation performance of risk management and GCG in banks operating in Indonesia by assessing bank soundness. The government has also made improvements to the bank's soundness rating system before 2014 using the CAMEL (Capital, Asset Quality, Management, Earning and Liquidity) approach. Then, from 2004 to 2011, the government used the CAMELS (Capital, Assets Quality, Management, Earning, Liquidity and Sensitivity) as set forth in PBI No. 6/10/PBI/2004 which was revised in 2011 using Risk-Based Bank Rating (RBBR) approach as set forth in PBI number 13/1 / PBI / 2011 and updated by POJK number 04 / POJK.03 / 2016.

The Financial Services Authority regulation, 04/POJK.03/2016, states that the rating of bank soundness is done by assessing the aspect of risk profile faced by the bank, the value of GCG implementation, earning and capital bank or also called risk, GCG, earning and capital (RGEC) approach. The improvement and refinement of the regulations governing the bank soundness rating aims to create a sound banking industry, namely the industry in which there are banks that have the capability to perform normal banking operations and can fulfill all their obligations well in a way, in accordance with the applicable regulations [Triandaru and Budisantoso, 2008: 51].

The creation of a sound banking industry that the government has undertaken has not been entirely successful as expected. The soundness score of private commercial banks listed on the Indonesia Stock Exchange has declined over the last five years still shows that on average the soundness of 18 banks or 56.25 per cent of 32 banks, which should have been a continuous increase.

Soundness score data of private commercial banks listed on the Indonesia Stock Exchange indicates that from 2012 to 2013 there is 13 or 40.63 per cent who experienced a decrease in soundness scores. Then, from 2013 to 2014 there was 26 or 81.25 per cent who experienced a decrease in soundness scores. Next, from 2014 to 2015 there is 10 or 31.25 per cent of which decreased soundness scores, and from 2015 to 2016 there was 15 or 46.88 per cent who experienced a decrease in Soundness scores. On an overall average in 2016, there is 18 or 56.25 per cent of private commercial banks listed on the Indonesia Stock Exchange which are experiencing a decline in Soundness scores.

This research is aimed to find the variables that become the antecedents of the bank soundness and to know the impact of moderation of good corporate governance (GCG) on the influence of risk to the soundness of private commercial banks listed in Indonesia Stock Exchange.

The critical objectives to be achieved in this research are:

1. Testing and analysing the effect of credit risk, market risk, liquidity risk, operational risk, and GCG implementation quality. In detail, the credit risk will be measured by an allowance for impairment losses on loans (CKPN's on Credit) and non-performing loan (NPL). Then, the market risk will be measured by interest rate risk (IRR) and net open position (NOP). Next, the liquidity risk will be measured by loan to deposit ratio (LDR), investing policy ratio (IPR and loan to assets ratio (LAR). Meanwhile, the operational 
risk will be measured by operating costs to operating income ratio (BOPO) and feebased income ratio (FBIR); and GCG implementation quality as measured by GCG selfassessment composite score on the soundness of private commercial banks listed on the Indonesia Stock Exchange.

2. Testing and analysing the impact of moderation of GCG on the impact of credit risk, market risk, liquidity risk and operational risk on the soundness of private commercial banks listed on the Indonesia Stock Exchange

\section{LITERATURE REVIEW AND HYPOTHESIS}

The rating of bank soundness in Indonesia has improved from the CAMELS approach to a riskbased approach (RBBR) with the issuance of PBI number 13/1/PBI/2011 and enhanced with POJK number 04/POJK.03/2016 stipulating that bank soundness rating include aspects of risk profile faced by banks, GCG implementation, profitability and capital performance.

The risk is a predictable or unforeseeable potential event that negatively impacts the bank's income and capital [Rivai et al., 2013: 549]. Understanding the risk implies that the risk is still in the form of potential, so that can be done to manage risk to minimise the occurrence of risk events and minimise the loss (risk loss). The researchers on risk management (Barriga \& Rosengren, 2004; Koch \& MacDonald, 2000; Crouhy, Galai \& Mark, 2000; Karpaviciene, 2006; Rowe \& Jovic, 2004; Sollenberger, 2004) concluded that the risks facing banks must be well managed [Cvilikas, 2010].

The legal basis for the application of risk management in the banking industry in Indonesia is PBI number 5/8/PBI/2003 which is then refined by PBI number 11/25/PBI/2009 and refined by the POJK number 18/POJK.03/2016 concerning Application of Risk Management for Commercial Banks. POJK number 18/POJK.03/2016 provides that commercial banks in Indonesia are required to manage 8 (eight) types of risk, of which four are credit risk, market risk, liquidity risk, operational risk can be measured using data from reports bank finance and four others namely legal risk, reputation risk, strategic risk and compliance risk cannot be measured using data from bank financial statements. This study only examines the risks that can be measured through bank financial statements.

Credit risk is a risk that occurs due to the failure of the counterparty failed to return loan principal and interest. Credit risk can be sourced from various functional activities of banks such as credit (provision of funds), treasury and investment as well as trade financing recorded in banking book and trading book (Rivai et al., 2013: 563). The financial ratios used to measure credit risk in this study are the ratio of CKPN to Credit and NPL. The ratio of CKPN and NPL negatively affects on credit risk and negatively affects on the soundness of banks, so credit risk adversely affects on the soundness of banks.

\section{H1: Credit risk has a significant effect on the soundness of private commercial banks listed on the Indonesia Stock Exchange.}

Market risk is the risk arising from the movement of market variables from the portfolio owned by the bank, which can harm the bank. Market variables are the interest rates and exchange rates, including the derivation of both types of market risk, namely the change in the option price [Rivai et al., 2013: 563]. The financial ratios used to measure market risk in this study are IRR and PDN ratios. IRR and PDN can positively or negatively affect to market risk (interest rate and exchange rate risk) and may positively or negatively affect to the bank's soundness so that the effect of interest rate risk and exchange rate risk on bank soundness is negative. 
H2: Market risk has a significant effect on the soundness of private commercial banks listed on the Indonesia Stock Exchange.

Liquidity risk (liquidity risk) is a risk caused by the bank is not able to meet all responsibility that mature [Rivai et al., 2013: 576]. The financial ratios used to measure liquidity risk in this study are the ratio of LDR, IPR, and LAR. LDR, IPR, and LAR can negatively affect on liquidity risk and can positively affect on bank soundness, so the influence of liquidity risk to bank soundness is negative.

\section{H3: Liquidity risk has a significant effect on the soundness of private commercial banks listed on the Indonesia Stock Exchange.}

Operational risk is the risk due to inadequacy and malfunction of internal processes, human error, system failure, and any external event affecting bank operations. Operational risk may be at any functional activity of the bank [Rivai et al., 2013: 579]. The financial ratios used to measure operational risk in this study are BOPO and FBIR ratios. BOPO has a negative influence on bank soundness, but FBIR has a positive influence on bank soundness, so the influence of operational risk to bank soundness is negative..

\section{H4: Operational risk has a significant effect on the soundness of private commercial banks listed on the Indonesia Stock Exchange.}

Good Corporate governance (GCG) is a form of relationship between board of commissioners, boards of directors, stakeholders and shareholders of a company including banks [Basel II, 2004], and GCG is a bank governance that applies principles of transparency, accountability, responsibility, independence and fairness [POJK number 55 / P0JK.03 / 2016]. GCG can positively influence the bank soundness. It can happen because if in a bank can be implemented GCG with high quality, it will have a positive impact on bank performance which in turn will also improve the financial soundness of bank banks. GCG in this study bank is measured by using the composite value of self-assessment GCG as published by each bank. Given that the composite value and predicate for GCG are inversely proportional, the composite value is reciprocal.

\section{H5: GCG has a significant effect on the soundness of private commercial banks listed on the Indonesia Stock Exchange.}

Risk is the potential loss due to the occurrence of an event [POJK number 18 / POJK.03 / 2016]. The risk faced by banks is very complicated, so it is essential for risk management in a bank that aims to minimise losses incurred by an event. GCG is bank governance that applies the principles of transparency, accountability, responsibility, independence and fairness (PBI number 8/14/PBI/ 2006). Banks that can implement GCG means that the bank has implemented good governance, so it will be able to provide excellent results for the bank. If the definition of risk and GCG is linked, it can be concluded that bank risk management carried out in conjunction with GCG will be able to minimise the negative impact of risk. Based on this logic, it can be concluded that the risks that may adversely affect the soundness of the bank will be minimised by the application of GCG in the bank.

H6-9: GCG moderates the effect of risk on the soundness of private commercial banks listed on the Indonesia Stock Exchange. 


\section{CONCEPTUAL FRAMEWORK}

The conceptual framework of this study is as shown in Figure 1. Figure 1 shows that the dependent variable of this study is bank soundness, and the independent variable is risk and GCG.

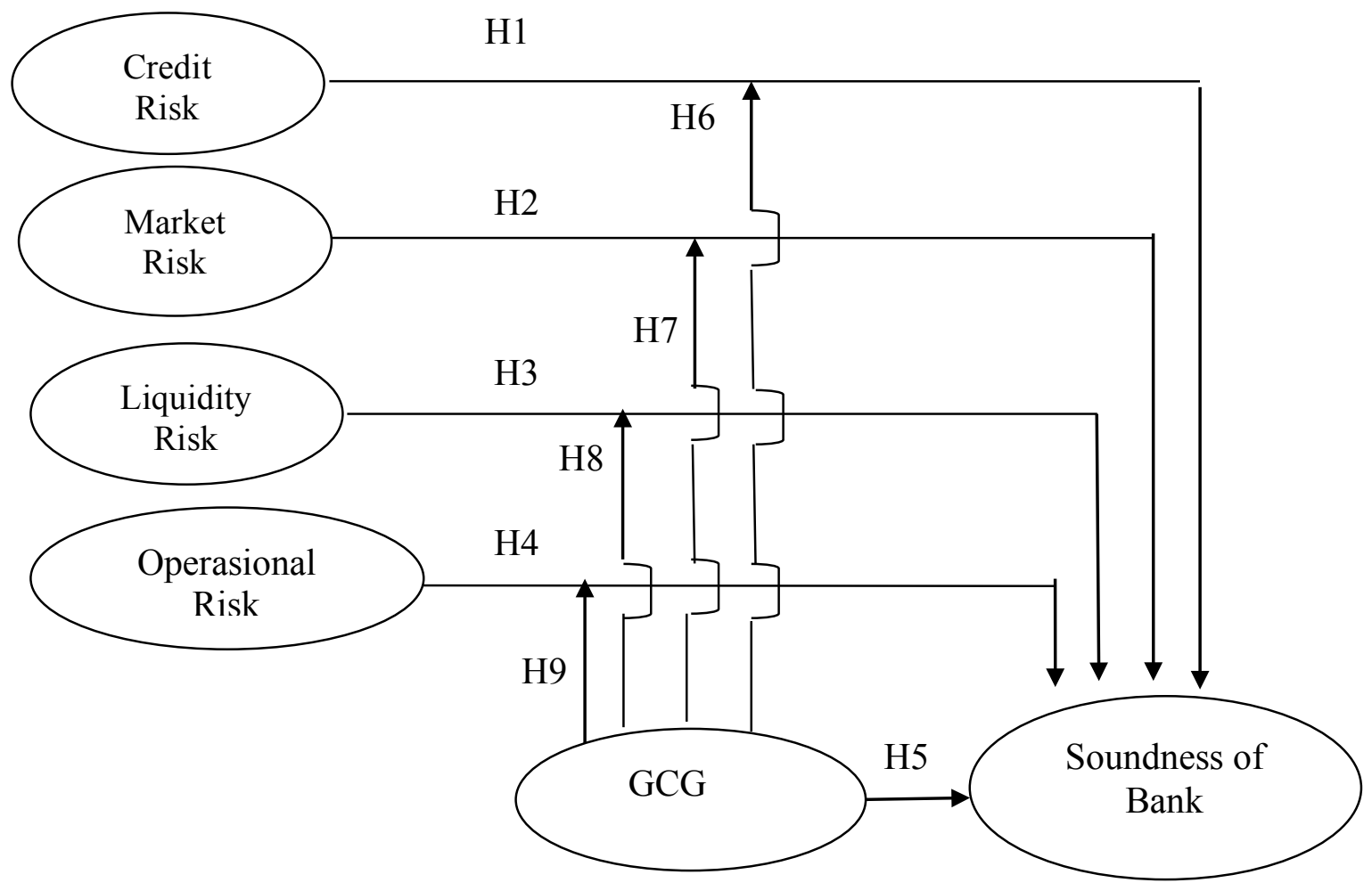

Figure 1: Conceptual framework

\section{RESEARCH METHODS}

The research method is a scientific way to get data with purpose and specific purpose (Sugiyono, 2017,2). This research includes the type of research using quantitative methods because of the research data in the form of numbers and analysis using statistics to test the hypothesis. Quantitative method is used if the problem is the starting point of research is clear, if the researcher wants to get broad information from a population and if the researcher intends to test the research hypothesis (Sugiyono, 2017,23). This research also includes descriptive research because the purpose is to explain the causal relationship between the variables through hypothesis testing and also a conclusive study because it meets the following characteristics (Malhotra, 2006: 84):

a. The aim is to test the influence hypothesis between the variables studied.

b. The required information is clearly defined.

c. Formal and structured research process.

d. Data analysis using quantitative techniques.

The population is a generalisation region consisting of objects or subjects that have a certain quantity and characteristics set by the researcher to be studied and then pulled the conclusion (Sugiyono, 2017,136). The population in this study are 34 private commercial banks listed on the Indonesia Stock Exchange period 2012-2016.

The sample is part of the number and characteristics possessed by the population. Researchers are unlikely to learn all that exists if the population is huge, and for that researchers can use samples taken from the population, so the sample is part of the population. The sample consists of a select number of members of the population (Sugiyono, 2017:137). The sampling 
technique used in this study is nonprobability sampling which is a sampling technique that does not provide opportunities or equal opportunity for each member of the population to be selected to be a sample (Sugiyono, 2017:142). The nonprobability technique the sampling used is purposive sampling, that is the technique of sampling with the specific consideration which is done by choosing the object based on the specific criterion specified by the researcher (Sugiyono, 2017:144). The criteria used in sampling in this study are as follows:

1. Private commercial banks listed on the Indonesia Stock Exchange in 2012-2016.

2. Private commercial banks that are still actively operating in Indonesia Stock Exchange until the end of the year 2016.

3. Private commercial banks that have soundness scores published by the InfoBank Research Bureau from 2013 to 2017.

4. A private commercial bank that publishes an annual report that has been audited using the closing year ending on 31 December.

5. A private commercial bank having a financial report certified by Bank Indonesia (BI) or the Financial Services Authority (OJK) to know the 2012 book by 2016

6. The financial statements are presented in Rupiah. This criterion is intended to obtain consistent data regarding monetary units.

The population selected as the sample based on these criteria is 22 banks, so the bank that became the focus of the research are 22 private commercial banks listed on the Indonesia Stock Exchange.

The variables analysed in this research include the dependent variable and the independent variable. The dependent variable is the financial soundness of the bank with the indicator of the bank's soundness score published by Infobank Magazine. Independent variable is business risk consisting of credit risk, market risk, liquidity risk and operational risk, and GCG quality Credit risk is measured by CKPN's financial ratios on Credit and NPL, market risk is measured by financial ratios of IRR and NOP, liquidity risk is measured by the financial ratios of LDR, IPR and LAR operational risks are measured by BOPO and FBIR financial ratios, GCG implementation quality as measured by GCG self-assessment composite score.

Data analysis technique begins with the collection of risk indicator data by searching and downloading the financial statements of private commercial banks listed on the Stock Exchange from 2012 to 2016 from the OJK website. Furthermore, taking the necessary data to be able to calculate the financial ratios that become research variables. GCG variable data were taken from the bank's annual report, and soundness level data were taken from Infobank magazine.

After data for all research variables are obtained, data analysis which includes descriptive analysis and statistic analysis. Descriptive analysis was used to describe the results of the study, and statistical analysis is used to answer research problems and prove the research hypothesis. Statistical analysis technique used is WarpPLS.

\section{ANALYSIS AND DISCUSSION}

The following explanations are descriptions of research variables: Credit risk, market risk, liquidity risk, operational risk, GCG and bank soundness.

\section{Credit Risk Variables}

The credit risk in this study was measured using the CKPN and NPL ratio indicators. 
CKPN samples during the study period from 2012 to 2016 tend to increase as evidenced by the average positive trend of 0.16 per cent. The increasing CKPN indicates that the reserve for impairment losses established by the sample research bank tends to increase, which means that during the research period of 2012 until 2016 the research sample banks have increased credit risk.

NPL samples during the study period from 2012 to 2016 tend to increase as evidenced by the average positive trend of 0.34 per cent. This increased NPL indicates that the problem loans that occur in the sample research bank tend to increase, which means that during the research period of 2012 until 2016 the research sample banks experienced an increase in credit risk.

\section{Market Risk Variables}

The market risk in this study is measured using the ratio of IRR and PDN.

The sample IRR during the study period from 2012 to 2016 tends to decrease as evidenced by the average negative trend of -1.32 per cent. This declining IRR if it is associated with an interest rate that tends to decrease during the study period as evidenced by the average trend of -0.01 per cent, then during the research period of 2012 until 2016 the sample research bank experienced an increase in market risk, especially the interest rate risk.

The sample PDN during the study period from 2012 to 2016 tends to decrease as evidenced by the average negative trend of -0.32 per cent. This declining PDN if it is associated with an exchange rate that tends to increase during the study period as evidenced by the average trend of 0.18 per cent, then during the research period of 2012 until 2016 the sample research bank experienced an increase in market risk, especially the exchange rate risk.

\section{Liquidity Risk Variables}

The liquidity risk in this study was measured only with IPR and LAR since the LDR ratio has a loading factor of less than 0.5 , so it is not included in the analysis.

The sample IPR during the study period from 2012 to 2016 tends to increase as evidenced by an average positive trend of 2.37 per cent. This increased IPR indicates the ability of research samples to fulfil their obligations to third parties by relying on increased securities which means that the liquidity of the sample research bank is increasing so that from 2012 to 2016 the sample research bank decreases liquidity risk.

LAR samples during the study period from 2012 to 2016 tend to decrease as evidenced by the average negative trend of -1.48 per cent. This declining LAR indicates the proportion of bank assets allocated to credit is decreasing so that the allocated to liquid assets increases. Increased asset allocation to this illiquid tool leads to increased bank liquidity which means that from 2012 to 2016 the sample research bank has decreased liquidity risk.

\section{Operational Risk Variables}

The operational risk in this research is measured by using the ratio of BOPO and FBIR.

BOPO samples during the study period from 2012 to 2016 tend to increase as evidenced by the average positive trend of 4.15 per cent. This increased BOPO indicates the inefficiency of the sample research bank regarding reducing operational costs to obtain operating income increased so that from 2012 to 2016 the sample research bank experienced an increased operational risk. 


\section{Variable Good Corporate Governance (GCG)}

Good Corporate Governance (GCG) variable in this study was measured using GCG score indicator.

The GCG sample score during the study period from 2012 to 2016 tends to increase as evidenced by the average positive trend of $0.97 \%$. This increasing GCG indicates that during the research period of 2012 until 2016 the sample research bank has improved the quality of good governance.

\section{Bank Soundness Variables}

The bank's soundness variables in this study were measured using bank soundness score indicators published by the Infobank Research Bureau. Sample soundness scores during the study period from 2012 to 2016 tend to decrease as evidenced by the average negative trend of -1.09 per cent. This declining soundness score indicates the soundness of the sample research banks has decreased, in other words, the soundness of the research samples during the study period of 2012 until the year 2016 has decreased.

The result of statistical analysis using WarpPLS Software is as shown in Figure 2 and Table 1. Based on Figure 2 and Table 1, it is found that the variables that have a significant influence on the soundness of private commercial banks listed on the Indonesia Stock Exchange are credit risk and operational risk because both variables have a p-value less than 0.05. Market risk, liquidity and GCG variables have an insignificant effect on the soundness of private commercial banks listed on the Indonesia Stock Exchange because these three variables have a p-value greater than 0.05 . The results of statistical analysis also show that GCG moderates the influence of credit risk, market risk, liquidity risk and operational risk to the soundness of private commercial banks listed on the Indonesia Stock Exchange because it has a p-value less than 0.05 . The discussion of the results of this statistical analysis is as follows.

The results of the study found that credit risk has a significant effect on the soundness of the research sample bank. The results of this study make the first hypothesis of this study which states that credit risk has a significant effect on the soundness of private commercial banks listed on the Indonesia Stock Exchange received. The effect of credit risk on the soundness of the sample research bank is in the opposite direction, meaning the decreasing the credit risk faced by the research sample bank, the soundness of the sample research bank will increase and vice versa if the credit risk faced by the sample research bank is increasing, research will decrease further. 


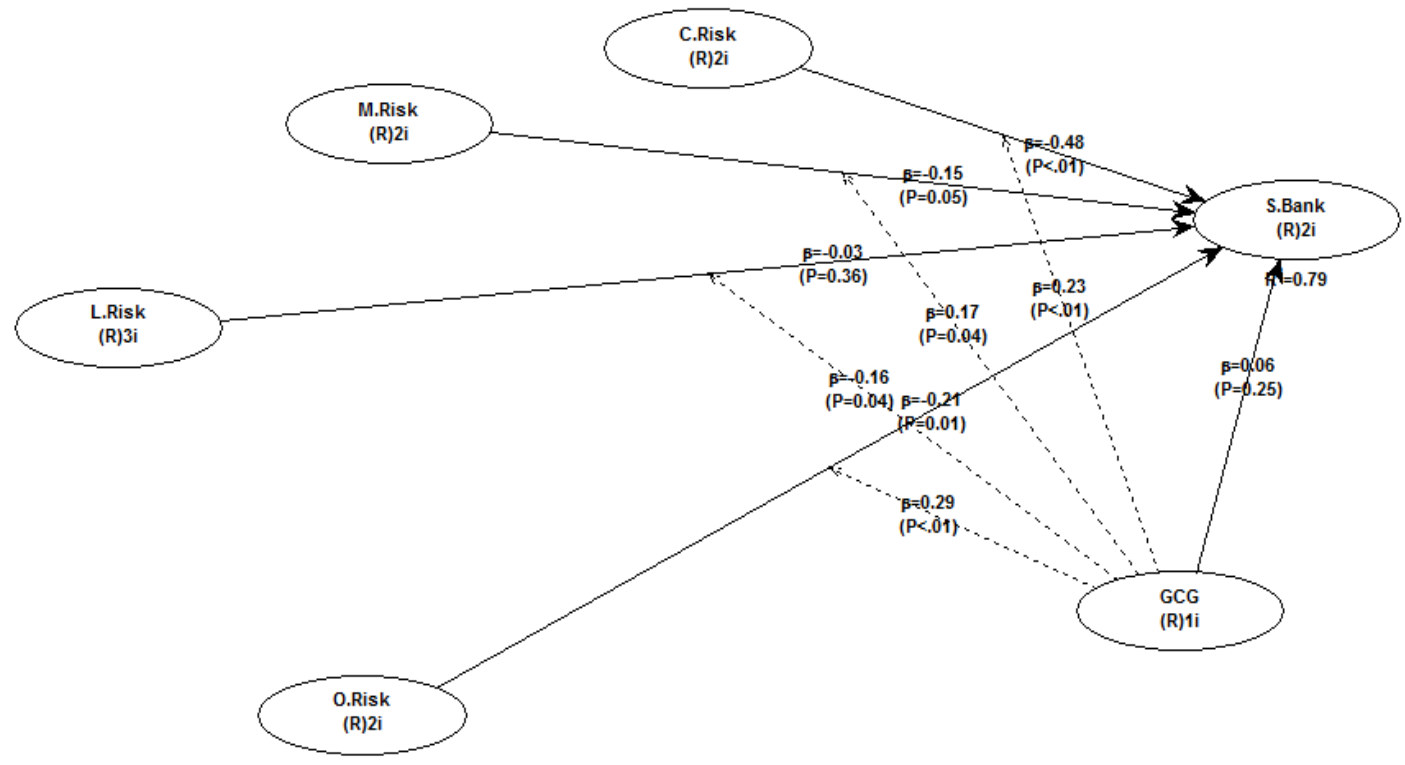

Figure 2: Output WarpPLS

Table1: Output WarpPLS

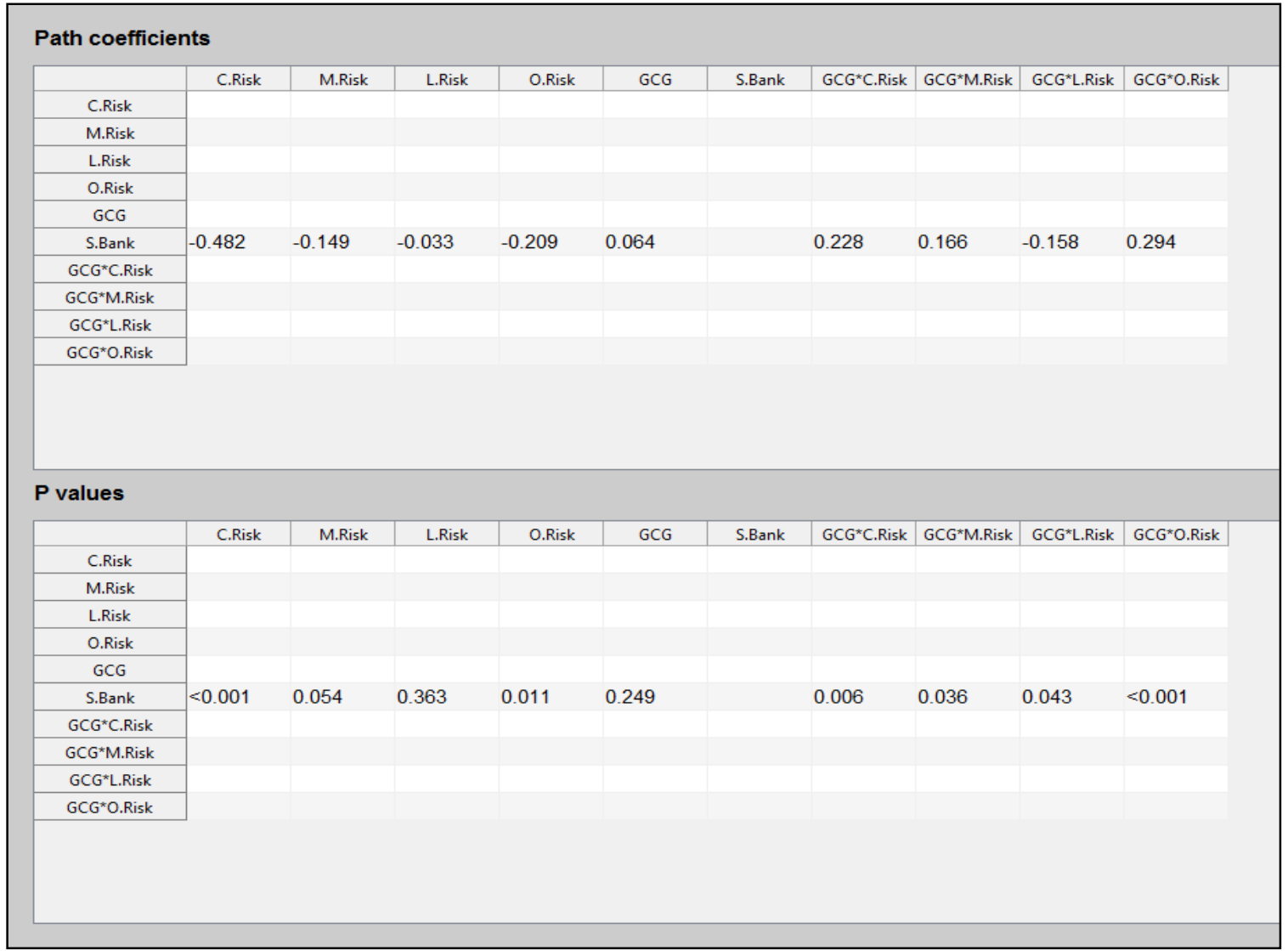

The results of this study also support the theory that the greater the risk faced by banks, the soundness of banks will be lower, and vice versa if the credit risk faced by the smaller banks, the financial soundness of banks will be higher. This can happen because if there is a failure in credit management, it can cause a lot of problem loans or bad debts that make credit risks increase and if a bank has much lousy credit or bad credit, it will lower the bank soundness (Bester, 1994, Bofondi and Gobbi, 2003 in Richard et al., 2008). 
The results of this study are in accordance with the practice of bank soundness assessment in Indonesia using Risk-Based Bak Rating (RBBR) approach or risk, good corporate governance, earning and capital (RGEC) approach, because if the credit risk faced by the bank decreases, the risk profile will increase, and assume that there is no change in the soundness score from other aspects of soundness assessment, the total soundness score will increase and should make the financial soundness of the bank increase, meaning the direction of counter-effect. This study finds a direction of influence that is also in opposite directions.

The results of this study support the results of previous research conducted Indira and Muljaman (1998) who found that the ratio of NPL as a measure of credit quality significantly negatively affect the financial soundness of banks. The decrease in NPL ratio will cause credit risk to decrease and decrease of credit risk will cause bank financial soundness increase. The results of this study do not support the results of research conducted by Haryati (2005) who found that the ratio of NPL has a significant positive effect on the financial soundness of banks. Haryati's research finds that if the NPL ratio of a bank increases, it will increase the credit risk and will cause the financial soundness of the bank to increase.

The significant impact of credit risk on the financial soundness of private commercial banks listed on the Indonesia Stock Exchange is due to the fact that during the period of credit risk research faced by the research sample banks increased as evidenced by the positive trend both in the ratio of CKPN to Credit as well as the NPL ratio. The increase in credit risk is coupled with the interest rate set by the Board of Governors of Bank Indonesia tends to decrease, thus causing decrease soundness scores on the aspect of risk profile that affects the decrease in total soundness score of the sample research bank.

The results found that market risk (exchange rate risk) had no significant effect on the soundness of sample research banks. The results of this study make the second hypothesis of this study which states that market risk has a significant effect on the soundness of private commercial banks listed on the Indonesia Stock Exchange was rejected.

The insignificant effect of market risk on bank soundness in this study is because from 2012 to 2016 the trend of NOP ratio of sample research bank positive which means forex assets is greater than the foreign exchange liabilities and tend to decrease as evidenced by the average trend of -0.32 . Positive and declining NOP ratio is exacerbated by the increase in the US Dollar exchange rate against the Rupiah, which means the value of the Rupiah weakened during the study period. The increase in the US dollar exchange rate is due to the increase in the Fed's interest rate from 2012 to 2016, wherein 2012 to 2014 it is 0.25 per cent, by 2015 by 0.5 per cent and by 2016 to 0.75 per cent. The increase of the US dollar against the Rupiah cannot be intervened by the Indonesian government because Indonesia uses a floating exchange rate system.

The results of this study support the results of research Santoso (2000) and Haryati (2005) who also found that the ratio of NOP as a measure of bank sensitivity to the market (exchange rate changes) has an insignificant effect on the financial soundness of banks.

The results of the study found that liquidity risk has no significant effect on the soundness of sample research banks. The results of this study make the third hypothesis of this study that states that liquidity risk has a significant effect on the soundness of private commercial banks listed on the Indonesia Stock Exchange rejected. 
The insignificant effect of liquidity risk on the soundness of the bank in this study is due to the minimum reserve requirement (GWM), especially the secondary reserve requirement that determines the small ratio of IPR as an indicator of liquidity risk of the research has met the existing provisions, but relatively stable during the period of research evidenced by trend ratio IPR is only 2.37 percent. GWM which has met the provisions of the provision of Statutory Reserves but relatively stable is what causes liquidity risks as measured by IPR in the study to be decreased, so it affects not significant to the soundness of private commercial banks listed on the Indonesia Stock Exchange.

The fact that the secondary reserve requirement set up by the sample research bank management is relatively stable, indicating that bank management only strives to meet minimum standards of stipulations that must be obeyed, and does not reserve funds much larger than the minimum requirements.

The explanation of the insignificant argument for the effect of liquidity risk on soundness banks is that the liquidity of commercial banks operating in Indonesia is strictly regulated by bank supervisors during the study period held by Bank Indonesia and then transferred to the Financial Services Authority. Regulations on liquidity that must be met by banks operating in Indonesia during the study period are PBI number 12/19/PBI/2010, PBI number 15/7/PBI/2013, POJK number 42 / POJK.03/2015 which is then enhanced Regulation of the Member of the Board of Governors of Bank Indonesia (PADG) number 19/4/PADG/2017.

The regulations on liquidity require that commercial banks be operating in Indonesia reserve funds derived from funds collected from the public (DPK) and should not be allocated to productive assets such as in the form of loans that will provide a relatively large income for banks. The reserve is referred to as the minimum reserve requirement of Statutory Reserves). The reserve requirement shall be 6.5 percent of the DPK in the form of primary preserve requirement in the form of cash, and 4 percent from third-party deposits in the form of securities, namely Bank Indonesia Certificates (SBI), Bank Indonesia Time Deposit (SDBI) Letter of State Treasury (SBN) and Government Securities (SUN).

The IPR ratio data describing the secondary reserve requirement established by the sample bank's management during the study period listed in Table 5.6 indicates that the study sample has been able to comply with the requirements of the Statutory Reserves during the study period set by the supervisor, but tends to be stable. This fact indicates that there is a tendency of bank sample management only to try to meet the minimum requirements and not to allocate large funds for reserve requirement.

The results of this study do not support the research of Meyer and Piefer (1970), Altman et.al (1977) and Indira and Muljaman (1998) who found bank liquidity as measured by Cash + Securities / Total Asset or IPR or liquidity ratio had a significant positive effect on failed / problem bank, but supported the research Sinkey (1975), Martin (1977), Gunther and Moore (2003) and Haryati (2005) who found to have an insignificant influence.

The results of this study do not support the results of research Meyer and Piefer (1970) and Sinkey (1975) who found that the LAR as a measure of bank liquidity has a significant negative effect on the financial health of the bank, and also Martin (1977) and Indira and Muljaman find LAR significant positive on the financial health of the bank.

The results of the study found that operational risk had significantly affected the soundness of the bank sample research. The results of this study make the fourth hypothesis of this study 
which states that operational risks have a significant effect on the soundness of private commercial banks listed on the Indonesia Stock Exchange accepted. The influence of the operational risk to the financial soundness of the sample research bank is in the opposite direction, meaning that the decreased operational risk faced by the sample research bank, the soundness of the sample research bank will increase and vice versa if the operational risks faced by the sample research bank is increasing, the soundness of the sample research bank will decrease further.

The results of this study also support the theory that the greater the operational risk faced by the bank, the soundness of the bank will be lower, and vice versa if the operational faced by the smaller banks, the soundness of the bank will be higher. It can happen because if the operational efficiency that occurs in a bank increases, then the operational risks faced by the bank will decrease. The decrease in operational risk will make the soundness of the bank increase.

The results of this study are also in accordance with the practice of bank soundness assessment in Indonesia using the Risk-Based Bak Rating (RBBR) approach or risk approach, good corporate governance, earnings and capital (RGEC), because if operational risk the bank's soundness score rises from the risk profile and assuming that there is no change in the soundness scores of other soundness assessment aspects, the total soundness score will decrease and decrease the financial soundness of the bank. In fact, the financial soundness of the sample banks decreased, as evidenced by the average trend of negative bank soundness scores (decreased) during the study period.

The results of this study support the previous research conducted by Meyer and Piefer (1970) and Haryati and Setiawan (2000) who found that the BOPO ratio or efficiency ratio had a significant negative effect on the financial soundness of the bank but did not support the research of Sinkey (1975) and Haryati (2005) which found that operational efficiency ratios or BOPO ratios had a significant positive effect on bank financial soundness.

The significant impact of operational risk on the financial soundness of private commercial banks listed on the Indonesia Stock Exchange is due to during the operational risk study period encountered by the increasing sample research bank as evidenced by the positive trend of BOPO ratio. This increase in operational risk caused a decrease in the soundness score on the risk profile aspect which resulted in a decrease in the total soundness score of the research sample bank.

The results of the study found that GCG had no significant effect on the soundness of research sample banks. The results of this study make the fifth hypothesis of this study stating that GCG has a significant effect on the soundness of private commercial banks listed on the Indonesia Stock Exchange was rejected.

There was no significant effect of GCG on the soundness of research sample banks because from 2012 to 2016 GCG was measured with the GCG score in this study shows an increasing trend as evidenced by the average trend of a positive GCG score. The increasing trend of GCG scores implies that the quality of governance in the sample research banks is increasing or improving, which should lead to the financial soundness of sample research banks. In fact, the soundness of sample banks decreased as evidenced by the average trend of negative bank soundness scores (declining) during the study period. Thus, the direction of GCG influence to financial soundness is unidirectional, but this study finds a direction of counter effect. 
The results of this study do not support the theory that the increased quality of governance in a bank, the soundness of the bank will increase, and on the contrary, if the quality of governance in a bank deteriorates, the soundness of the bank will decrease. The results of this study are also not in accordance with the soundness assessment practices of banks in Indonesia that use the Risk-Based Bak Rating (RBBR) approach or risk approach, good corporate governance, earnings and capital (RGEC), because if the GCG faced by banks increases, the soundness score banks from the GCG aspect will increase, and assuming that there is no change in soundness scores from other aspects of soundness assessment, the total soundness score will increase and should make the soundness of the bank increase. This study found an increasing GCG, but the financial soundness of banks declined.

Research on the influence of GCG on the soundness of banks is still very little done by researchers in the past. Research conducted by Hutama (2013) found that GCG has a significant effect on bank soundness, only this research from normality point of view, while other researchers have not tested the effect of this variable on bank soundness.

The results of this study support the results of research conducted by Hutama (2013) who found that GCG has a significant effect on bank soundness, it is just that Hutama's research is from a normative legal point of view, while a GCG score measures this researcher of the quality of governance.

The findings of the study found that GCG as a moderator influences credit risk, market risk, liquidity risk and operational risk to the soundness of the sample research bank. The results of this study led to the sixth, the seventh, eighth and ninth hypothesis of this study stating that GCG moderates the influence of credit risk, market risk, liquidity risk and operational risk to the soundness of private commercial banks listed on the Indonesia Stock Exchange.

The results of this study cannot be compared with the results of previous studies, as previous studies did not test the moderate impact of GCG on the effect of credit risk on the financial health of banks.

\section{SUMMARY}

Based on the description presented earlier, it can be seen that in this study produced the research findings which can be explained as follows:

1. Credit risk has a significant effect on the soundness of the bank strengthening the findings of research conducted by Indira and Muljaman (1998) who found that NPL as a measure of credit quality that can also be used as an indicator of credit risk significantly negatively affect the financial soundness of banks. The decline that occurs in NPLs will cause credit risk to decrease and decrease credit risk will cause financial soundness of banks to increase.

The results of this study do not support the results of research conducted by Haryati (2005) who found that NPL has a significant positive effect on the financial soundness of banks. Haryati's research finds that if the NPL of a bank increases, it will increase credit risk and will cause financial soundness of the bank increases.

2. Market risk has an insignificant effect on bank soundness strengthening research findings conducted by Santoso (2000) and Haryati (2005) which also found that PDN as a measure of bank sensitivity to market (exchange rate) has an insignificant effect on bank financial soundness.

3. Liquidity risk has no significant effect on bank soundness. The result of the research support researchs conducted by Meyer and Piefer (1970), Altman et.al (1977) and Indira and Muljaman (1998) who found that bank liquidity as measured by Cash + Securities / Total Assets or IPR or liquidity ratios have a significant positive influence 
on bank failures / problems. However, it differs from research of Sinkey (1975), Martin (1977), Gunther and Moore (2003) and Haryati (2005) which find no significant influence. In addition, the results of this study do not support the results of the research by Meyer and Piefer (1970) and Sinkey (1975) who found that LAR as a measure of bank liquidity had a significant negative effect on the financial soundness of banks, and also Martin's (1977) and Indira and Muljaman studies that found LAR had a positive effect significant to the financial soundness of banks.

4. Operational risk has a significant effect on the soundness of the bank. The results is in line with the research conducted by Meyer and Piefer (1970) and Haryati and Setiawan (2000) who found that the BOPO ratio or efficiency ratio had a significant adverse effect on the financial soundness of banks. However, it is in contrast with Sinkey's (1975) and Haryati (2005) who found that the operational efficiency ratio or BOPO had a significant positive effect on bank financial soundness.

5. GCG has no significant effect on the soundness of banks, strengthening the findings of research conducted by Hutama (2013) found that GCG has a significant effect on the soundness of banks, it's just that this research is from a normative legal point of view, while the researcher of the quality of governance as measured by GCG scores.

6. GCG moderates the effect of credit risk on bank soundness as new findings from this study, as no previous studies have examined the impact of GCG moderation on the effect of credit risk on bank financial soundness.

7. The GCG moderates the effect of market risk on bank soundness as new findings from this study, as no previous research has examined the impact of moderation of GCG on the effect of market risk on bank financial soundness.

8. The GCG moderates the effect of liquidity risk on bank soundness as new findings from this study, as no previous research has examined the impact of GCG moderation on the effect of liquidity risk on bank financial soundness.

9. GCG moderates the effect of operational risk on bank soundness as new findings from this research, as no previous research has examined the impact of GCG moderation on the effect of operational risk on bank financial soundness.

\section{LIMITATION}

Based on the result of the study, the researcher assumes that all the findings cannot fully answer all the problems related to the used variables namely credit risk, market risk, liquidity risk, operational risk, good corporate governance (GCG), earning, and capital. The limitation of the research is expected to be used as reference material of the next researcher, and it will also give a contribution to the next study. Limitations of the study are as follows:

1. Incomplete data on the soundness scores of banks that become the population of this study, so that members of the population are not included in the process of determining the sample research

2. Incomplete data on bank financial statements published through BI and OJK sites, so that the incomplete data is not included in the sample determination process.

\section{ACKNOWLEDGMENTS}

This research received assistance from many parties, therefore with the completion of this research, researchers thanked the Directorate of Research and Community Service, Directorate General of Research Strengthening,and Development Ministry of Research, Technology and Higher Education which sponsored this research. Thank you also to the chairman of STIE Perbanas Surabaya, Chairperson of PPPM STIE Perbanas Surabaya who provided facilities to researchers to complete this research 


\section{References}

Altman, E.I., Robert G.H., and P. Narayan. 1977, Zeta Analysis: A New Model to Identify Bankruptcy Risk of Corporations, Journal of Banking and Finance, pp 29-54.

Aryati T and Shirin Balafif, 2007, Analysis of Factors Affecting Bank Soundness With Logit Regression, Winner Journal, vol 8 no 2, pp111-125.

Bank Indonesia, 2003, Bank Indonesia Regulation (PBI) Number 5/8/PBI/2003 dated May 19, 2003, concerning the Application of Risk Management for Commercial Banks, Bank Indonesia, Jakarta.

, 2004. Bank Indonesia Regulation (PBI) Number 6/10 / PBI / 2004 dated April 12, 2004, concerning the Soundness Rating of Commercial Banks, Bank Indonesia, Jakarta.

, 2006. Bank Indonesia Regulation (PBI) Number 8/4 / PBI / 2006 dated 1 January 2006, regarding the Implementation of Good Corporate Governance [GCG] for Commercial Banks, Bank Indonesia, Jakarta.

, 2006. Bank Indonesia Regulation (PBI) Number 8/14 / PBI / 2006 dated 5 October 2006 regarding the Amendment of PBI Number 8/4 / PBI / 2006 concerning Implementation of Good Corporate Governance [GCG] for Commercial Banks, Bank Indonesia, Jakarta.

, 2009 Bank Indonesia Regulation No. 11/25 / PBI / 2009 dated July 1, 2009 regarding the amendment to Bank Indonesia Regulation Number 5/8 / PBI / 2003 concerning the Implementation of Risk Management for Commercial Banks, Bank Indonesia, Jakarta.

,2010, Bank Indonesia Regulation (PBI) No: 12/19 / PBI / 2010 dated October 4, 2010, concerning Minimum Mandatory Giro Commercial Banks In Indonesian Banks In Rupiah And Foreign Currencies Banks, Bank Indonesia, Jakarta.

,2011, Bank Indonesia Regulation (PBI) No: 13/1 / PBI / 2011 dated January 5, 2011, concerning Rating of Soundness Level of Commercial Banks, Bank Indonesia, Jakarta.

2013, Circular Letter of Bank Indonesia (SEBI) No: 15/15 / DPNP April 292013 Implementation of Good Corporate Governance for Commercial Banks, Bank Indonesia, Jakarta.

,2013, Bank Indonesia Regulation (PBI) No: 15/7/ PBI 2013 dated October 1, 2013, concerning Minimum Mandatory Giro Commercial Banks In Indonesian Banks In Rupiah And Foreign Currencies Banks, Bank Indonesia, Jakarta.

2017, Bank Indonesia Regulation (PADG) No: 19/4/PADG/2017 dated April 28, 2017, concerning Minimum Mandatory Giro Commercial Banks In Indonesian Banks In Rupiah And Foreign Currencies Banks, Bank Indonesia, Jakarta.

Basel Committee on Banking Supervision, 1988, International Convergence of Capital Measurement and Capital Standards, Basel Committee On Banking Supervision, Basle.

1996, Overview Of The Amendment To The Capital Accord To Incorporate Market Risk, Basel Committee On Banking Supervision, Basle.

, 2004, International Convergence Of Capital Measurement and Capital Standards, A Revised Framework, International Convergence Of Capital Measurement and Capital Standards, Arevised Framework, Basel Committee On Banking Supervision, Basle.

2009, A global regulatory framework for more resilient banks and banking systems, Basel Committee On Banking Supervision, Basle.

Cvilikas, 2010, The Structure of Decision for Banking Risk Management's Economic Efficiency Assessment. Journal of Economic and Management, Vol 15, pp 893-899.

Financial Services Authority, 2015, OJK Regulation number 42 / POJK.03 / 2015, December 23, 2015, concerning Resposibility To Fulfill Liquidity Adequacy Ratio (Liquidity Coverage Ratio) For Commercial Bank, OJK, Jakarta.

, 2016, OJK Regulation number 04 / POJK.03 / 2016, January 26, 2016, on the Soundness Assessment of Commercial Banks, OJK, Jakarta.

, 2016. OJK Regulation number 18 / POJK.03 / 2016, March 16, 2016, concerning Application of Risk Management for Commercial Banks, 0JK, Jakarta.

, 2016. OJK Regulation number 55 / POJK.03 / 2016, December 7, 2016, concerning Implementation of Good Corporate Governance for Commercial Banks, OJK, Jakarta.

, 2017. Circular Letter OJK number 13 / SEOJK.03 / 2017, March 17, 2017, on the Implementation of Good Corporate Governance for Commercial Banks, OJK, Jakarta. 
Gilbert R.A., Andrew P.M., and Mark D.V., 2002, Could a CAMELS Downgrade Model Improve Off-Siet Surveillance ?, The Federal Reserve Bank of St. Louis, January-February, 47-64.

Gunther and Moore, 2003, Early Warning Model in Real Time, Journal of Banking \& Finance, 27, pp 1979-2001.

Haryati S and Joko Budi Setiawan, 2000, Performance Analysis of Frozen Banks Operations, Takeovers, Recapitalization and Soundnessy Banks 1992 -1998, Journal of Business Economics and Accounting Ventura, Volume 4, No 2, pp 97-107.

Haryati S, 2005, Study of Prediction Model of Bank Indonesia National Private Banking Level, Journal of Business Economics and Accounting Ventura, Volume 9, No. 3, pp 1-19.

Hutama R H, 2013, Good Corporate Governance As One of the Soundness Rating Factors of Commercial Banks, Privat Law Journal, Vol 3, No. 1, pp 35-52.

Indira and Muljaman, 1998, Predicting Banking Conditions Through a Dynamic Solvency Approach, Bulletin of Monetary Economics \& Banking, 2, pp $169 \neg 184$.

Infobank Research Bureau, 2013, Infobank Magazine, "Soundness Rating of Banks in Indonesia". June 2013 Edition, InfoBank Research Bureau, Jakarta.

,2014, Infobank Magazine, "Soundness Rating of Banks in Indonesia". June 2014 Edition, Infobank Research Bureau, Jakarta.

,2015, Infobank Magazine, "Soundness Rating of Banks in Indonesia". July 2015 Edition, Infobank Research Bureau, Jakarta.

2016, Infobank Magazine, "Soundness Rating of Banks in Indonesia". June 2016 Edition, Infobank Research Bureau, Jakarta.

,2017, Infobank Magazine, "Soundness Rating of Banks in Indonesia". July 2017 Edition, Infobank Research Bureau, Jakarta.

Malhotra, Naresh K. 2006, Marketing Research An Applied Orientation, Prestice Hall, United State of America.

Martin D., 1977, Early Warning of Bank Failure, Journal of Banking and Finance, 1, pp 249-276.

Meyer and Pifer, 1970, Prediction of Bank Failure, The Journal of Finance, pp 853-868.

Richard E., Marcelina C., Erasmus K., Christer P., and Hakan B. 2008. Credit Risk Management System of A Commercial Bank in Tanzania, International Journal of Emerging Markets, Vol. 3. No. 3, pp 323-332.

Rivai V., Sofyan Basir, Sarwono Sudarto and Arifiandy Permata Veithzal. 2013. Commercial Bank Management: Banking Management From Theory To Practice. PT. Raja Grafindo Persada, Jakarta.

Santoso W., 2000, The Determinants of Problem Banks in Indonesia [An Empirical Study., Htp: www.bi.go.id/bank. Sinkey Joseph F.Jr., 1975, A Multivariate Statistical Analysis of The Characteristics of Problem Banks, The Journal of Finance, XX, pp 21-36.

Sugiyono, 2017, Business Research Methods, Quantitative Approach, Qualitative, Combinations, and R \& D, Third Edition, ALFABETA, Bandung.

Triandaru S. and Totok Budisantoso, 2008, Bank and Other Financial Institutions, Fourth Edition, Salemba Four, Jakarta. 